\title{
Follow the Leaders in Newbery Tales
}

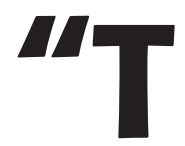

oday's youth are tomorrow's leaders." This statement, or some variation of it, can be seen on billboards, promotional brochures, and advertisements for a variety of organizations and institutions. However, the time lag implicit in the statement reveals a misunderstanding about youth leadership; after all, aren't today's youth today's leaders? Young leaders are less like dormant seeds and more like saplings that need nurturing, pruning, and strengthening to develop.

The youth leadership garden can be tended right now by providing growing leaders with young adult novels in which young people are putting their leadership skills and perspectives into practice (Hanna, 1964; Hayden, 1969; Friedman \& Cataldo, 2002). What better books for this purpose than the venerable Newbery Medal winners? This prestigious award has been given to authors since 1922 , encouraging creativity, emphasizing the significant contributions authors make, and giving children's librarians an opportunity to promote good writing. Because all literature is born in a context, it seems that a content analysis of carefully selected Newbery works could yield information about leadership perspectives. So I set out to discover what leadership perspectives exist in Newbery realistic fiction, and in the pages of those books I met some amazing adolescent leaders who
My interest in the characters themselves led me to look at them in a broader way, to see what picture of leadership readers would get as they vicariously faced the challenges the protagonists faced and experienced the consequences of their actions. weren't waiting for adulthood before putting their skills to productive use.

I selected eight leadership perspectives for this study, all of which have been well documented in studies of leadership, are cited in comprehensive resources on leadership, and provide a good overview of the range of interpretations possible when analyzing leadership. These perspectives include the personality, formal, democratic, political, subjective, ambiguity, moral, and the cultural/symbolic perspectives (Table 1). In the process, I looked for the answers to four questions: (1) What leadership perspectives are evident? (2) Which perspectives are dominant? (3) Does the portrayal of the perspectives change over time? (4) Does the gender of the protagonist have an effect on leadership perspective?

I examined seventeen Newbery Medal winning fiction books, each with a protagonist between twelve and fifteen years old, that convey a variety of leadership perspectives cloaked in narrative form (Table 1).

While my study focused on identifying leadership perspectives in the selected stories, my interest in the characters themselves led me to look at them in a broader way, to see what picture of leadership readers would get as they vicariously faced the challenges the protagonists faced and experienced the consequences of their actions. So, a narrow focus drove my 
Table 1: Perspectives, Descriptors, and Cited Summary Descriptions

\begin{tabular}{|c|c|c|}
\hline Leadership perspective & $\begin{array}{l}\text { Descriptors characteristic of } \\
\text { those displaying perspective }\end{array}$ & Cited summary descriptions \\
\hline Personality perspective & $\begin{array}{l}\text { Possessing physical traits, cognitive } \\
\text { abilities, affective abilities, supernatural } \\
\text { traits, creativity }\end{array}$ & $\begin{array}{l}\text { Leadership is a function of the } \\
\text { leader's charisma and personal traits } \\
\text { (Starratt, 1993; House, 1997; } \\
\text { Northouse, 1997); leaders can be } \\
\text { heroes with supernatural ability to } \\
\text { lead (Gardner, 1995); vision of leader } \\
\text { inspires others (Starratt, 1993). }\end{array}$ \\
\hline Formal perspective & $\begin{array}{l}\text { Creating structures promoting leader- } \\
\text { ship, demonstrating and/or valuing } \\
\text { efficiency, demonstrating management } \\
\text { skills, valuing productivity, valuing } \\
\text { action }\end{array}$ & $\begin{array}{l}\text { Leadership exists to create, maintain, } \\
\text { and manage the workplace so that } \\
\text { productivity goals are met (Bush, } \\
\text { 1995) and vertical and horizontal } \\
\text { structures are maintained (Yukl, } \\
\text { 1998); management, not leadership, } \\
\text { is primary (Northouse, 1997); } \\
\text { emphasis is on action not traits } \\
\text { (Carlson, 1996). }\end{array}$ \\
\hline Democratic perspective & $\begin{array}{l}\text { Demonstrating expertise, attempting to } \\
\text { build consensus, sharing responsibility }\end{array}$ & $\begin{array}{l}\text { Every voice in an organization must } \\
\text { be heard (Bush, 1995); consensus- } \\
\text { building a hallmark (Bush, 1995; } \\
\text { Carlson, 1996); personal initiative } \\
\text { valued (Fiedler, 1967); expertise } \\
\text { honored (Bush, 1995). }\end{array}$ \\
\hline Political perspective & $\begin{array}{l}\text { Manipulating others to retain power, } \\
\text { negotiating to maintain control, using } \\
\text { compromise to retain power; dark side } \\
\text { of Democratic perspective }\end{array}$ & $\begin{array}{l}\text { Negotiation and compromise are } \\
\text { needed to move an organization } \\
\text { forward (Bush, 1995). Power is a } \\
\text { driving force (Pfeffer, 1992); interest } \\
\text { groups influence decision making } \\
\text { (Bush, 1995; Carlson, 1996). }\end{array}$ \\
\hline Subjective perspective & $\begin{array}{l}\text { Expressing interpretations of situations, } \\
\text { acknowledging changing realities, } \\
\text { demonstrating personal qualities } \\
\text { resulting in power; less desirable } \\
\text { complement of Personality perspective }\end{array}$ & $\begin{array}{l}\text { Individuals' interpretations create the } \\
\text { reality of an organization (Bush, } \\
\text { 1995). Personal qualities, not position } \\
\text { in the organization, determine } \\
\text { leadership roles (Bush, 1995). }\end{array}$ \\
\hline Ambiguity perspective & $\begin{array}{l}\text { Expressing uncertainty about the } \\
\text { leadership situation, experiencing } \\
\text { unpredictability, ambiguity, chaos, and } \\
\text { disorder, relying on luck or chance }\end{array}$ & $\begin{array}{l}\text { Leaders will have trouble with } \\
\text { purpose, experience, and success } \\
\text { (Bush, 1995) and will experience } \\
\text { inevitable unpredictability and } \\
\text { uncertainty (Bush, 1995). }\end{array}$ \\
\hline Moral perspective & $\begin{array}{l}\text { Valuing followers' personal growth, } \\
\text { relying on a guiding principle to make } \\
\text { decisions, putting own interests behind } \\
\text { those of followers }\end{array}$ & $\begin{array}{l}\text { Organizational leaders exist to } \\
\text { strengthen individuals (Greenleaf, } \\
\text { 1980; DuPree, 1990), acknowledge } \\
\text { individual interpretations (Bush, } \\
\text { 1995), and lead a moral enterprise } \\
\text { (Sergiovanni \& Starratt, 1998). }\end{array}$ \\
\hline Cultural/Symbolic perspective & $\begin{array}{l}\text { Referring to or creating group codes/ } \\
\text { symbols, acknowledging importance of } \\
\text { rituals, participating in ceremonies }\end{array}$ & $\begin{array}{l}\text { As an active transformer of society } \\
\text { (Starratt, 1993), the leader acknowl- } \\
\text { edges rituals and symbols of } \\
\text { organization (Bush, 1995) and } \\
\text { engages others in discussions which } \\
\text { promote renewal of the organization. }\end{array}$ \\
\hline
\end{tabular}


research, but a broader view captured my interest. While I will briefly identify the perspectives I discovered, I'll focus my discussion on the stories as wholes, thus giving my reader the opportunity to choose books from this set to read, enjoy, and use as leadership models. The books I analyzed included:

1. Crispin: The Cross of Lead (Avi, Hyperion, 2002)

2. Dicey's Song (Cynthia Voigt, Atheneum, 1982)

3. A Gathering of Days (Joan W. Blos, Macmillan, 1979)

4. It's Like This, Cat (Emily Cheney Neville, Harper \& Row, 1963)

5. Jacob Have I Loved (Katherine Paterson, Crowell, 1980)

6. Johnny Tremain (Esther Hoskins Forbes, Houghton Mifflin, 1943)

7. M.C. Higgins, the Great (Virginia Hamilton, Macmillan, 1972)

8. Missing May (Cynthia Rylant, Orchard, 1992)

9. The Midwife's Apprentice (Karen Cushman, Clarion, 1996)

10. Onion John (Joseph Krumgold, Crowell, 1959)

11. Out of the Dust (Karen Hesse, Scholastic, 1996)

12. A Single Shard (Linda Sue Park, Clarion, 2001)

13. The Slave Dancer (Paula Fox, Bradbury, 1973)

14. The Trumpeter of Krakow (Eric P. Kelly, Macmillan, 1928)

15. Up a Road Slowly (Irene Hunt, Follett, 1966)

16. A Year Down Yonder (Richard Peck, Dial, 1998)

17. Young Fu of the Upper Yangtze (Elizabeth Foreman, Winston, 1932)

\section{Leadership Perspectives}

In order to focus on identifying, quantifying, and analyzing the eight common leadership perspectives, I created a code book derived from an analysis of research conducted about the eight perspectives, assigning a code to significant, contiguous blocks of text, counting the number of times each of the thirtyeight possible codes appeared, and ranking the codes by prevalence.

For example, the personality perspective was analyzed using the following codes derived from a review of leadership literature. I added Code 1.6 after I noticed its prevalence in the Newbery literature and absence in the code book:

1.1 The protagonist has physical traits that indicate leadership.
1.2 The protagonist has cognitive abilities that indicate leadership.

1.3 The protagonist has affective abilities that indicate leadership.

1.4 The protagonist has supernatural traits that indicate leadership.

1.5 The protagonist has other traits consistent with the personality perspective.

1.6 The protagonist has creative/artistic abilities that indicate leadership.

Performing the content analysis in this way allowed me to determine which of the eight perspectives were most and least common in this subset of Newberys. Most of the books conveyed multiple perspectives. The moral perspective came out on top (16 of the 17 books), followed by the personality and ambiguity perspectives (14/17), the subjective $(9 / 17)$, the democratic $(6 / 17)$, the political $(4 / 17)$, and the formal and cultural/symbolic (3/17).

While these and other corollary findings were gratifying to discover (after all, moral leadership won a rousing victory), it was even more interesting to have the opportunity to get to know the literary leaders in these fiction works as well as I did, so well that their stories interested me far more than the leadership perspectives on which I focused my attention. The protagonists in these stories exhibit behavior ranging from bossy arrogance to meek humility to noble service. They participate in a variety of leadership tasks; leading a country to revolution (Johnny Tremain) and protecting the ashes of a loved one on a journey home (Dicey Tillerman) are just two examples. The seventeen authors who gave birth to this brood of eight girls and nine boys call them "hero," "prodigal son," and "outcast." Of the seventeen, most are Caucasian, two are Asian, and one is African American. They are a diverse lot, and they react to the scripts written for them in diverse ways. The leadership summaries that follow will allow the reader to enjoy getting acquainted with this group of leading adolescents.

\section{Whole-book Rankings and Summaries}

What follows is a summary of each book, written to focus on the leadership activities, attitudes, and behaviors in each book as a whole. Instead of introducing the protagonists and their stories in historic 
order, they will be introduced in order of strength of leadership perspectives portrayed in the books under consideration. The focus in the research study was on the protagonist and his or her leadership perspective(s); the focus here is on the books as whole units, thus highlighting that a good story transcends the sum of its parts. So, for example, while the protagonist may be a strong leader, the tasks (s) he had to accomplish may diminish the overall reading experience (e.g. The Trumpeter of Krakow and M.C. Higgins, the Great). The purpose of this method is to highlight the "wholeness" of each piece of literature.

The order presented below was arrived at by assigning each book a 5, 4, 3, 2, or 1 (high to low) in terms of five categories: (A) Strong, clear leadership perspectives(s) presented in protagonist's activities, attitudes, and behaviors; (B) Believable leadership tasks within probable plot; (C) Balanced protagonist who exhibits normal range of human emotions; (D) Engaging story; (E) Other leaders who also inhabit the story. Ranking results are presented in Table 2; bold type indicates books with a female protagonist.

This whole-book ranking produced the following results ranked from strongest to weakest leadership perspective. Ties within each place are presented chronologically:

$1^{\text {st }}$ place: The Slave Dancer; Dicey's Song; A Single Shard

$2^{\text {nd }}$ place: Johnny Tremain

$3^{\text {rd }}$ place: Out of the Dust; Crispin: The Cross of Lead $4^{\text {th }}$ place: Young Fu of the Upper Yangtze; The

Midwife's Apprentice; A Year Down Yonder

$5^{\text {th }}$ place: Onion John; Jacob Have I Loved

$6^{\text {th }}$ place: The Trumpeter of Krakow; M.C. Higgins, the Great

$7^{\text {th }}$ place: Up a Road Slowly; Missing May

$8^{\text {th }}$ place: A Gathering of Days

$9^{\text {th }}$ place: It's Like This, Cat

\section{First place (1 of 3): The Slave Dancer by Paula Fox}

Ironically, the book that received one of the highest whole-book rankings has one of the most reluctant leaders in the sample. Thirteen-year-old Jessie Bollier is kidnapped from the streets of New Orleans in the mid-nineteenth century. Told he is going on a "fine sea voyage" (p. 11), he quickly discovers that that is a gross misrepresentation of the truth. In fact, Jessie's talent for playing the fife has landed him on the ship; his dreadful leadership role is to play tunes to make the slaves-that soon will inhabit the filthy holds-dance, so that they arrive at port in marketable condition. His confusion is understandable, and expressed often in this first-person, historical fiction account.

Jessie fulfills his role, sometimes belligerently, but mostly uncertainly. He feels his "life [has] turned upside down" (p. 51), and he spends much of the rest of his journey expressing his confusion in contrasting couplets: he hates the crew's cruelty but admires their fearlessness (p.40); he dislikes one man's slowness but thinks his sudden burst of energy repulsive (p.71); he remembers the delight he felt when he spied on a young woman undressing The protagonists in these stories exhibit behavior ranging from bossy arrogance to meek humility to noble service. They participate in a variety of leadership tasks; leading a country to revolution (Johnny Tremain) and protecting the ashes of a loved one on a journey home (Dicey Tillerman) are just two examples. but is mortified as he is now allowed to look at the naked bodies of the slaves (p. 75). Jessie tries to make sense of the contradictions in his new-found life, but his interpretations of his role in the sorry affair leave him unsatisfied. Even though he pities the slaves, he grows to hate them for being the reason he is on the boat in the first place (p. 79).

As master of the slaves' exercise program, Jessie performs his duties with dread, so much dread that his music suffers (p. 101). In fact, he exhibits few personality traits that would make him fit for the task he has been pressed into. He does sort out the personalities of the crew, and he avoids those who will bring him harm. The rich cast of characters he learns to interpret include the dangerous Captain Cawthorne, kind Purvis, dishonest Stout, and unfortunate Spark, a Mate who was bound and thrown overboard after killing a murderous slave-thus reducing the profit the Captain will reap. The crew members' leadership roles 
are prescribed and rigid, and Jessie often cannot see the logic in the actions of others on board.

As if this human drama were not enough to keep the reader interested, Fox increases the tension in the final chapters of the book. When it becomes clear to the captain that an American ship has discovered their dirty trade, he orders all the shackles thrown overboard. Before the splash of the iron restraints hits the deck, the slaves are hurled overboard too. From this point forward, The Slave Dancer belongs to Jessie Bollier. Whether the leadership tasks he has been forced to perform or his own resources guide him, he takes charge and helps Ras, a slave boy his own age, escape the chaos on the deck. As the weather and the behavior of the crew become rougher and rougher, Jessie and Ras hide below deck, sharing a bit of food and "strange conversation" (p. 127), given that neither speaks the language of the other. The bond serves them well; they manage to survive the storm that crushes the ship (the only ones on board who do survive). Jessie's heroic actions lead them to land and to safety. Daniel, the man who finds and cares for them, leads Jessie to his home and Ras to freedom in the north.

\section{First place (2 of 3): Dicey's Song by Cynthia Voigt}

Getting kids ready for school, holding a job, planning for the family's future, restoring a boat, and helping a child with a learning disability are uncommon tasks for most 13-year-olds. Dicey Tillerman, though, is a rather uncommon person. Her position as the oldest of four gives her the status she needs to ensure cooperation from the younger kids, and the unfortunate situation of being parentless (due to her father's absence and her mother's mental illness) creates a void that Dicey is ready and willing to fill. She is as confident in her leadership role as Jessie of The Slave Dancer is hesitant in his. This contemporary story opens at Gram's house in Maryland, the destination that Dicey and her siblings hoped to reach from Boston before summer ended.

Grateful to Gram for taking them in, Dicey decides that having a job would ease the burden, so she negotiates hours and duties for herself with a local shopkeeper. She recognizes the same reading disability her young sister has in Millie, her employer, and Dicey broadens her influence at the store by helping her fill out merchandise order forms. Likewise, at home, Dicey's self-imposed responsibilities increase; sister Maybeth's inability to read is making her lag behind the other third-graders. Dicey consults and cooperates with others to solve this problem creatively and successfully. So, with 30 pages down and over 300 to go, how is Dicey going to keep up this leadership pace? Fortunately, Gram rescues her: "You're not the only one responsible, girl. You've been responsible a long time and done a good job. Take a rest now.” (p. 37).

Dicey takes the advice, though the book hardly becomes Gram's Song. Dicey spends more time restoring her beloved boat, but even this activity becomes an opportunity to help brother Sammy figure himself out. James, her oldest brother, becomes her idea man; she realizes he has the brains while she has the management skills needed to carry out the plans he concocts. She tries to follow Gram's guiding principle-"Hold on to people. They can get away from you” (p. 126) - advice which Dicey thinks may reveal her grandmother's own regrets.

Though Dicey handles adult responsibilities better than many adults, she doesn't fare as well in ageappropriate situations. She snubs and avoids two peers who show interest in her, she refuses to achieve in classes that don't hold her interest, and she is falsely accused of plagiarism when she writes an essay about her ailing mother. Mina, a classmate who shares Dicey's intellectual capabilities, declares, "You are a hard person to be friends with, Dicey Tillerman" (p. 84). But friends they become, and Dicey continues to learn that being part of a group can help one tackle life's problems. Gram's adoption of the four siblings is concrete evidence of the truth of that statement.

At the end of the story, life's problems come to Dicey's world via the postal service. Gram receives a letter from Boston, and she makes hasty plans to travel there with Dicey. Dicey follows, literally most of the time, as Gram leads her to her dying mother's hospital room. As Dicey takes a break from the emotional scene to buy Christmas gifts for the others, she experiences the kindness of strangers.

Galvanizing Gram's guiding principle-reach out and hold on to those you love-both Gram and Dicey discover who the dying woman was to them personally. Dicey leads the way home by calling and telling 
her siblings the news and by carrying her mother's ashes in a hand carved wooden box that a sympathetic stranger gave to her. Though Dicey is again completing adult tasks, she does so with less pride and more good will to others who reach out to her, realizing the "confusion [called life] was going to be a permanent condition” (p. 359).

\section{First place (3 of 3): A Single Shard by Linda Sue Park}

Both of the other first place finishers in this whole-book leadership ranking lived and led in adult worlds. Likewise, Tree-ear, a Korean orphan from the 1100's, wakes each day to forage for food for himself and his elderly companion Crane-man. For many in his situation, that would be the end of the story. But 12-year-old Tree-ear's curiosity, courage, and creativity transform him from lackey to hero, and much more.

Tree-ear's historical fiction adventure begins as he patiently, daily, fetches clay and wood to be used by the potter, Min, as he creates his celadon-tinted pottery, renowned in all of Korea. He has a debt to pay to Min, a master potter, and it was Tree-ear himself who suggested he toil for the man whose work he had carelessly broken. However, when the obligation is paid, Min keeps Tree-ear on as a willing servant, a very fortunate choice for both master and boy.

Tree-ear picks up the trade quickly, and daily he hopes for the chance to make a pot on the wheel. Min's wife shows kindness to him, even providing food and clothing that he shares with Crane-man. His own personality serves him well in his new life: he is courteous, curious, and contemplative. His humility (fostered by cultural norms) leads him to credit good fortune with much of his happiness.

But it is curiosity and a respect for doing the right thing that turns the tale into a great adventure. Treeear notices that a rival potter, Kang, is trying out a new technique, one that will be sure to catch the Emperor's eye and earn him the highest honors. Knowing that taking ideas that do not belong to him is stealing, Tree-ear waits to tell Min of the pottery method. When Kang's work is put on public display, Tree-ear knows that the idea belongs to everyone, and he shares the secret of the inlaid design with Min. Min, being a greater craftsman than Kang, produces two beautiful vases to be presented to the Emperor, in hopes of gaining a lifetime commission. Tree-ear volunteers to deliver them to the capital, Songdo, a journey that will take many weeks. He is pleased when Min accepts his offer, but is heartbroken when Min also tells him that he will never teach him to make pottery; that honor can only be bestowed on a son, and Min's son died long ago.

He leaves Crane-man in the care of Min's wife (being careful to guard his elderly friend's pride by telling him that she needs his help with household tasks), and he begins the journey that each day "is only as far as the next village” (p. 93). Nearing his destination, Tree-ear is robbed and his precious cargo is thrown over a cliff. Recovering a single shard which shows the handsome inlaid handiwork of his master, he continues on, gains the royal commission, and returns home. His happiness turns when he finds out Crane-man has died, but returns when Min helps him construct a pottery wheel and Min's wife addresses him as a son.

\section{Second place (1 of 1): Johnny Tremain by Esther Forbes}

Another historical fiction character joins his male counterparts Tree-ear and Jessie in the Newbery exemplary-leadership lineup. His emotional life isn't as balanced as Tree-ear's and, unlike Jessie's tale, the length of the story makes it lose its steam by the time it reaches its destination. Like Dicey, he is a leader from the first page in the story, a story that includes fictionalized details about many leaders in early American history. He is a poster boy for the personality perspective. He's "boss of the attic [workshop], and almost of the house” (p. 2) and, though his personality softens a bit, he finds ways to be in charge throughout the story that ages him from 11 to 16 .

Johnny, like Tree-ear, is a craftsman's apprentice. He is talented at silver smithing, and he is arrogant about his skill. He orders, argues with, and belittles the boys who work alongside him, and his "semisacred" ability (p. 4) and ability to read and write make him a rival, not a companion. He even disputes his master when he thinks it is necessary, and, fortuitously, obtains work from John Hancock after doing so. To top this hubristic personality off, he also has three names, unheard of among poor folk, and this link to a wealthier past proves to be both a 
stumbling block and a step up in the future. Johnny is setting himself up for a fall-which comes in the form of an "accident" which burns his hand and renders it useless for silver work. His detailed future plans disappear, and his new life in pre-revolutionary America begins.

Lucky for him, Rab, another orphan a few years older than he, gives him a delivery job for the The Observer, a newspaper. As a role model, Rab shows him how to dress to impress, how to temper his volatile personality, and, most importantly, how to be a member of the Sons of Liberty revolutionaries. When he is falsely accused of stealing a silver cup which his mother gave him (the inscription "Lyte" links him to a wealthy merchant), Rab and Johnny's friend Cilla help in obtaining his release and in earning the anger of the wealthy man.

His life as a secret patriot begins well: he tames a spirited horse-“an almost impossible thing” (p. 93), learns about politics and current events, masters the use of his left hand, reads prolifically, and continues, through Rab's prodding, to modify his character. His quest for revenge on Dove, the boy who orchestrated the maiming accident, fades as his interest in regaining his lost silver cup rises. The old, unsettled Johnny still surfaces.

However, he has earned the "implicit trust" (p. 117) of Samuel Adams, and Johnny is one of the many Sons of Liberty leading the Boston Tea Party. He is entrusted with delivering codes, blowing the whistle for action, and remembering a secret countersign, which he repeats to Paul Revere. Through Rab's help, he earns a job delivering messages for a British doctor. By doing so, he discovers the plans of the British and helps the patriot's cause. His crippled hand keeps him from learning to shoot, but his intellect keeps him at the center of the revolutionary drama. He predicts war will come as he interprets the events around him. When given the opportunity to take back the cup that is rightfully his, he refuses to have anything to do with the wealthy British: "This is the end. The end of one thing-the beginning of something else. ... [T]he cards are going to be reshuffled. Dealt again . . ." (p. 165).

The "something else" that is soon to begin frightens Johnny, for he is not prone to violence. Sam Adams asks Johnny to call the rebels together, and at the ensuing meeting Johnny realizes that the local fight is a battle against tyranny everywhere. His leadership in it takes on heroic status, and his work as a spy results in early victories. He befriends a British stable boy and negotiates a trade: a disguise for the boy so he can escape in exchange for his musket. But the young deserter is caught and shot, and Johnny wonders if he himself has as much courage as his role model Rab. His dreams evoke his wakeful leadership fears.

When Rab goes off to war with the musket Johnny acquired for him, Johnny's world turns upside down: "He half wished he might cry and was half-glad he was too old for tears." (p. 209). His continued spying helps alert the patriots; his continued quest for real action is denied. He has a role to play, and he saves many lives by doing it well. In a strange twist, he becomes the heir to the Lyte fortune: His mother was a Lyte, and, in an even stranger twist, his wealthy relative symbolically bestows the family fortune on him as she touches his widow's peak-"all that he had ever got from the beautiful Vinny Lyte [his mother]" (p. 235).

In disguise, Johnny surveys the war landscape. He discovers that Rab has been shot, and he comforts his friend before he dies. He is numb from all the bloodshed and confusion, but as the doctor remedies his crippled hand by cutting the scar, Johnny also is freed from his crippling experiences, now able to see the larger significance-human freedom-of the current events in the American colonies.

\section{Third place (1 of 2): Out of the Dust by Karen Hesse}

Billie Jo is a protagonist who likes to think things through. She muses and interprets her way through the hardships of life. Her personality and introspective nature are reflected in this first-person historicalnarrative poem. Rather than producing the tedious rambling of a 14-year-old, however, the author skillfully personalizes a very difficult time in a family's life and in America of the 1930s.

Billie Jo tells us at the very beginning of the story that her daddy wanted a boy; thus, her feminized male name. Later in the story, Billie reveals that Ma is pregnant again, so the future is full of hope, even though dust, wind, and drought threaten their Okla- 
homa farm. Billie Jo has quite a life to live. She is an accomplished pianist, and she negotiates with her mom to let her accept an invitation to play weekly at the Palace, a local club. Her dreams to earn money to help the family and to play someday for President Roosevelt seem to be on track. Smart, talented, and honest, she rises above the chaos of dust and debt, joking about the family's "peppered” potatoes and "chocolate milk" (p. 21):

when really all our pepper and chocolate, it's nothing but dust.

She also is surly, loves companionship, tries to figure out her mom, and wants to move away. In other words, she is a character most adolescent readers could understand.

It's that identification with the protagonist that makes what follows so compelling. Ma, preparing coffee, mistakes a pail of kerosene for water, and pours "a rope of fire" (p. 60) from pail to stove. As Ma runs outside for help from Daddy, Billie Jo wisely grabs the burning pail and flings it out of the door. But Ma was on her way back in, and she turns in to a "column of fire" (p. 61). More painful than the burned hands (cf. Johnny Tremain) that keep her from her piano are the nightmares Billie Jo has as she watches her Ma and baby brother die (p. 64):

Daddy called to me. He asked me to bring water, Ma was thirsty.

I brought up a pail of fire and Ma drank it. She had given birth to a baby of flames. The baby

burned at her side.

Billie takes on a familial leadership role at the funeral. When her father does not respond when asked the baby's name, Billie Jo names him “Franklin," after her beloved President Roosevelt. Faulting her father for putting the kerosene by the stove in the first place, Billie Jo grows uncertain, afraid, and a co-leader in a household where she is quietly resented.

She continues to interpret life through analogies, and the encouragement of others makes her try playing the piano again. In little ways, hope seems to be returning: she longs to see a bigger world, she continues to do well in school, and she's inspired by the creativity of others. She tries to fill the void left by her mother, but Daddy is preoccupied and distant, believable reactions given that:
Dust

piles up like snow

across the prairie,

dunes leaning against fences,

mountains of dust pushing over barns. (102)

The whole community is in the same boat, and others are even less seaworthy than Billie Jo's (Out of the Dust) family. She takes the challenge, sharing and serving others who also are drowning in dust. She emulates Ma's previous action by donating her brother's feed-sack nightgown to a newly born baby. This generosity is a temporary catharsis; Billie's piano playing earns third place at the Palace talent contest.

Billie Jo knows that she is no substitute for the wife that Daddy now seems to be looking for. As another bout of dust descends, Billie Jo seems even more in need of escape. She leads a car and lost driver through a storm, thinks of the cattle dying of muddy lungs, eats food laced with grit, and sees hopelessness in her father's eyes. Life has to be better somewhere else.

So she leaves. Getting on a train in the middle of the night, she heads west, out of the dust. Her boxcar escape transforms her; a man who left his family also rides the rails away, and she realizes that her place is with her father:

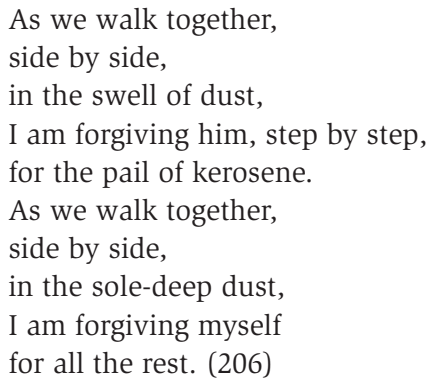

She leads her dad to physical and emotional healing by convincing him to seek treatment for the dust cancer on his face and by accepting his new wife. Billie Jo leads herself home.

\section{Third place (2 of 2): Crispin: Cross of Lead by Avi}

The second third-place whole-book leadership contender is 13-year-old Crispin, an orphan living in medieval England. Unlike the orphans before him, Dicey, Tree-ear, and Johnny, he has even bigger problems than finding food and work. Like Johnny, he 
has a secret past, is falsely accused of theft, and learns the meaning of the word "freedom;" unlike Johnny, he lives in a more dangerous time where courts of law are hanging ropes. His life is endangered early on in this first-person historical fiction tale; the reason why is not resolved until the end.

Crispin is a product of his world; as a serf he feels both fortunate-he does have food, and unfortunatehe is not free to choose a life for himself. He expects God to produce both prizes and punishments, and he is sure he deserves the latter most often. He is shunned, even as his mother lives; he is hunted when he becomes an orphan. Known only as Asta's son, he doesn't know he has his own name-Crispin-until his friend Father Quinel tells him. All of this ambiguity adds up to mass confusion: For reasons unknown to him, Crispin has been declared a "wolf's head" by the manor's steward; he can be killed without fear of retribution, a most disgraceful situation to be sure. The kind priest gives him his mother's lead cross, into which she scratched an inscription. He was not aware that she could read and write, and he certainly cannot, so he looks forward to the priest's promised explanation.

Which never comes. The priest is murdered, and Crispin is pursued, finding himself leaving the only life he knows. He relies on Christ, crosses, saints, and signs for protection, protection that ironically comes in the form of a mere man named "Bear." Crispin swears a sacred oath to this unpredictable man, and his life as a juggling musician's apprentice begins. Bear recognizes Crispin's talent and wit, but chides him for his religious beliefs: "As God is near-and surely He always is-He needs no special words or objects to approach Him” (p. 99). As if Bear's view of the next world were not shocking enough, he tells Crispin that he is his own master. Crispin's worldview is rocked: "Surely God Himself put us all in our places: Lords to rule and fight. Clergy to pray. All the rest-like mewere on earth to labor, to serve our masters and our God” (p. 101). Meek Crispin hardly sounds like an exemplary leader, but this story is full of surprises.

Under Bear's guidance, Crispin learns his trade. He is shocked when Bear upsets the global order by giving him the coin he earned entertaining others. He remains undetected, though rumors about the "wolf's head" circulate through the towns and villages they visit. Bear continues to help him interpret experiences, transforming him from servant to master, and teaching him to think for himself-essentials for the leadership task he will perform later.

His first experience of consciously choosing to be his own master turns disastrous. He leaves the lodging he and Bear share, even after being warned not to. He is recognized and pursued. His skill and plan help him escape, but it takes Bear to make a full rescue. He begs forgiveness, but Bear says none is needed because it is he who has forgotten how little Crispin really knows. Though his own past is mysterious to him, he is beginning to piece together Bear's true life as a leader in a rebellion against the norms of medieval England. His suspicions are confirmed by the widow who provides them lodging. She urges Crispin to look out for Bear-to preserve the life of both master and servant. Crispin's leadership role has been defined.

Fortunately, Crispin has many personality characteristics which help him through the ambiguity that crowds around him. He is observant, and he notices when armed men are about to invade the place where Bear and his compatriots are meeting. Furthermore, he recognizes that one of the men is John Aycliffe, the steward of the manor and the one who has declared him a "wolf's head," so he puts himself in mortal danger when he alerts Bear and his band. Bear assists the others as they escape, but he himself is captured. He cries out, "Go Crispin. Get out of the city. It's you they want, not me" (p. 204).

Crispin returns to the widow's ransacked house. He comforts her, and she reveals what has been secret to him throughout the tale: His cross is inscribed with the words, "Crispin-son of Furnival." Though Crispin thinks he understands the significance of the revelation-Lord Furnival is nearing death and Crispin has a claim to his land-the widow makes it plain: "What ever noble blood there is in you is only ... poison. Lady Furnival, who's the power here, will never let you have the name. She'll look on you as her enemy, knowing that anyone who chooses to oppose her will use you and what you are” (p. 217). Her other revelations about his past make his present clear: Bear is being held as bait to catch him.

He takes the bait, frees Bear from torture, and negotiates their release. He boldly declares himself Lord Furnival's son, and compromises his own noble position by saying that if he and Bear are escorted safely out of the town gates they never will return nor 
claim his rights. To seal the deal he agrees to hand over the cross, the only evidence short of DNA testing that proves his parentage. They are double-crossed and a bloody fight ensues; Crispin and Bear gain the upper hand. True to his word, Crispin lays his cross of lead on the steward's body and, accompanied by Bear, emerges from the town "a full member of the guild of free men" (p. 261).

\section{Fourth place (1 of 3): Young Fu of the Upper Yangtze by Elizabeth Foreman Lewis}

The second (and final) Asian protagonist in the sample is Young Fu. He has much in common with other protagonists in previous rankings. Like Tree-ear, Johnny, and Crispin, he is an apprentice. He lives in China, a world proscribed by rules and roles, as does Crispin; but, unlike Crispin, he early-on questions the social order and suggests new interpretations. He is fatherless like Jessie Bollier, but Young Fu's mother is less a victim of circumstances than Jessie's is. Though he leads in many ways, the episodic nature of this historical fiction story set in the early 1900s fails to engage the reader as fully as the stories in previous rankings.

Young Fu begins his life in the city of Chunking, apprenticed to the coppersmith Tang. He is ridiculed as a country bumpkin, but he is driven to learn the trade so his mother will have life's necessities. His mother's superstitious ways are not his; for example, he shows no fear of foreigners who, according to his mother, could bring harm just by catching one's eye.

He learns the ways of the shop and city. Running errands for Tang, he becomes familiar with the city. He remains curious throughout the story, even after being victimized by a soldier. Work demands his time, but he longs to learn to read and write. Though he knows his duty is to Tang, he takes time to observe Chinese writing, and he welcomes Wang Scholar's offer to teach him. However, he disappoints his wise neighbor by failing to see the ultimate value of learning: "It has been given that men might learn how to live, not to win fortune" (p. 54), Wang teaches. The lesson takes. Young Fu vows to live a life that is honorable to his father and ancestors. This proves a difficult promise to keep; immediately afterward he gets lost in thoughts of his own self-importance and damages the copper piece he was sent to deliver. Young Fu seems like a leader, but, as yet, an unpolished one. Once again he vows to do better, and he hopes his success will mean his mother does not have to work anymore.

His skill and knowledge increase (as does his overweening pride). He is conned into buying a watch and then sells snow ("Dragon's Breath") to pay his debt. His quick mind causes him to doubt superstitions; so, despite his mother's warnings against foreigners, he rushes to watch as fire burns the foreign hospital. Serendipitously, he helps a foreigner save her house from the widening fire, an action which reaps future benefits. The grateful woman rewards him with money; Young Fu gives her a gift from the shop in return. He imagines what wealth a foreign patronage might bring the shop, and he concludes that, twice, he has tested superstitions and won.

Predictably, his bold defiance of accepted social norms produces fruit. When his friend Small Li collapses, he decides that the foreign woman can help him. He uses humor, charm, and negotiating skill to convince Li's very traditional family to try the foreigner's remedy. Small Li is cured and would surely have died from his ruptured appendix otherwise.

Next, Young Fu accompanies Tang on a journey down the river, to deliver brass pieces to a customer. He is honored to have been asked. He saves the silver that has been given in payment for the brass by hiding it under himself, undergoing severe discomfort as he is stepped on by the bandits in his hiding place. Again, his ability and personality save the day. His pride, once again, surfaces as he plans to share his tale with his shop mates. His mother's superstitions are voiced again, but, even so, Young Fu doesn't mind his next adventure either: spending the night outside the city gates. When the river floods, it's Young Fu to the rescue! He leads many who live outside the gates to safety. His charisma and courage save the day.

When revolutionaries begin ruining businesses and attacking citizens, Tang puts Young Fu in charge of the shop while he is away. Young Fu turns away intruders, but narrowly escapes death due to Tang's intervention. Young Fu continues to think about his many experiences, to question superstitions and prejudice, to learn to read and write, and to look forward to owning his own shop. Echoing the confidence his employer has in him, his mother leaves him 
alone while she travels to visit a sick relative. Unfortunately, Young Fu gambles away the money she left him. He worries that she won't trust him, and strikes a bargain with Tang to repay his debt. She is pleased when she returns, "you are beginning to fill your father's place in the household" (p. 195), and admires him for his honesty about the gambling debt.

But his episodes of leadership are not over. He discovers his master's stolen pieces in the marketplace, and his status and wages continue to rise. Though he credits the gods for his success, his drive to do well for his master also motivates him. Like Treeear, his merits are noticed by his employer, who treats him as a son. Like Dicey, he is adopted, and wears the garments in which "he would resemble one of Tang's intimates rather than an employee” (p. 228).

\section{Fourth place (2 of 3): The Midwife's Apprentice by Karen Cushman}

The fourth apprentice in the sample is also the first female apprentice in this whole-book ranking. Her life is ambiguous from the start: She is of indeterminate age (12 or 13), and her name changes in five pages from "Brat," to "Beetle," to "The Midwife's Apprentice." Her intelligence and cleverness get her into this job, and her personality gets her reinstated at the end of the tale. Furthermore, she dubs herself "Alyce," and she makes a practice of symbolically legitimizing the people and animals around her by giving them respectable names.

She learns early on that "midwife's apprentice" doesn't necessarily mean "birth helper." It seems she is more of a "supply carrier." She's quite sure the midwife doesn't want to reveal her secret skills and spells, but she is smart and observant and picks up the trade in her own way. She doubts that superstition and magic have much to do with the process (cf. Young $\mathrm{Fu}$ ), though later in the story she may wish she had had some magical intervention.

Forced into tending alone to a mother in labor, she panics. Trying the midwife's own routine of verbal assault on the laboring woman produces results: a shower of household implements thrown at her, but no baby born. When the midwife herself comes to the rescue, she slaps the mother, forces wormwood tea down her throat, and, order restored, delivers a baby. Beetle is frightened by the chaotic leadership situation she was forced into (cf. Jessie Bollier), but is even more afraid of being "turned cold and hungry out of the midwife's cottage” (p. 24).

A case of mistaken identity transforms "Beetle" to "Alyce," and she decides that, hard as it may be, she will answer only to that name. She proceeds to bestow the same favor on others; as though she were Adam himself, she names the cat, the cow, and the young boy she rescues, symbolically transforming them to creatures with lives of worth. She can be noble, but she can be manipulative too. Alyce dupes the superstitious villagers into thinking the Devil himself has been wandering through the town, visiting those who have been less than scrupulous. The Devil leaves indeterminate tracks in the snow as he wanders about, courtesy of the blocks of wood Alyce carved just for this deceptive purpose. Not only does she gain retribution, she also reveals (only to the reader) her logical mistrust of superstitions (cf. Young Fu).

She is getting bolder and more skillful; some grateful mothers even pay her for her help, thus earning a little for herself (cf. Crispin). Ironically, she learns that kindness can assist a birth better than insults not through her experiences with human birth, but by watching a farm boy help twin calves enter the world ("Twins, Alyce!" cried Will. "You have brought me great luck, for Tansy be having twins” [p. 51]). She crafts her own trade by combining the best of what kindness and the midwife have to offer. Much more, now, than "the midwife's hand or arm" (p. 53), Alyce is learning to lead in her own way, though she worries about easing reluctant babies into the light, a

foreshadowy foreboding. Her failure to do so for a villager named Emma forces her to leave the best life she has yet known.

She finds a place for herself and her cat at an inn, as kitchen sweeper and mouse chaser. A guest at the inn befriends her and teaches her to write letters. He respects her enough to ask what she wants, to which she replies, "A full belly, a contented heart, and a place in the world" (p. 81). She needs the help of others to see that she is entitled to those things, and, ironically, it is her hard-hearted mistress who gives her courage to try her craft again.

But not right away. Before she returns to Jane she makes sure Edward, the boy she rescued earlier, is safe, and she delivers a baby from a woman who didn't know she was pregnant. Her courage comes 
from remembering the words and advice of those in her past, and she returns to her "place in the world" (p. 81), to Jane's house, to a future as the midwife's apprentice.

\section{Fourth place (3 of 3): A Year Down Yonder by Richard Peck}

Though this protagonist has less of a strong, clear leadership perspective than others rated lower overall, the believable protagonist and the strong supporting actress kept it in fourth place in the whole-book ranking. Though the story is in the first-person narrative point of view, it seems less about "I" and more about the quirky grandma who the reader learns to love early on. It takes the protagonist longer to love her.

Hard times have hit Chicago in 1937, and desperate measures were used to survive. Mary Alice, 15, is sent south to live with her grandmother (cf. Dicey): "No telephone ... . [Y] ou had to go outdoors to the privy. Nothing modern” (p. 2). In other words, no good. But good does come to Mary Alice; though, with a sneaky, manipulative, heart-of-gold grandmother to watch out for, the road to happiness is a bumpy one. Most of Mary Alice's time is spent trying to stay two steps behind Grandma: she plays along as Grandma teaches a neighbor a lesson, she helps make glue that will mark the boys who intend to knock over her privy, she's a partner in crime as Grandma steals pumpkins and pecans to make pies for charity, and she watches as Grandma manipulates others to raise money for a needy woman. "I walked in Grandma's shadow” (p. 61) sums life up well.

Mary Alice is not entirely passive, however. She recognizes bad omens ( $\mathrm{cn}$. Young $\mathrm{Fu}$ and $\mathrm{cf}$. Crispin) as she gets ready to play the lead in the Christmas nativity, a show that is talked about (for various reasons) for many years. Mary Alice begins to love Grandma by looking past her quirks to that good that inspires her. Mary Alice reaches out to others, adopting Grandma's manipulative ways as necessary: She pens anonymous "Newsy Notes" for the local newspaper, revealing harmless gossip and highlighting community shortcomings in her cryptic words, and she orchestrates a Valentine scam to deflate the ego of an overbearing classmate. But she's a mere amateur in the conniving department: As Mary Alice entertains her hoped-for-boyfriend Royce, Grandma, shotgun in hand, scares a woman clad only in a snake out of the attic she has rented to an artist. Mary Alice thinks the embarrassment will end her life, but of course, Grandma has other plans for her.

Mary Alice's concern and care for Grandma grows. She leaves graduation practice to check on her during a tornado. Grandma passes the kindness on by checking in on ailing neighbors during the storm. With Grandma as role model, they together clean up the community. It comes as no surprise when the author fast forwards through time, and the reader learns that Mary Alice will be married in her beloved grandma's house.

\section{Fifth place (1 of 2): Onion John by Joseph Krumgold}

If the tenth book in this whole-book ranking followed suit with the previous nine, the protagonist should be the product of a home split by death, abandonment, uncertain paternity and/or financial hardship. But it doesn't fit the pattern. Onion John is like an Ozzie-and-Harriet breath of fresh air in a place grown stale from the problems defining it. Twelveyear-old Andy starts his first-person narrative proclaiming the value of team work, and the book retains that theme throughout. He wins the championship baseball game by hitting a home run. He shares the credit for the win with his teammates, and he credits luck and superstition with partial responsibility (cn. Young Fu and Alyce, cf. Crispin and Mary Alice). Preferring to visit his friend John in the dump instead of joining the team for an ice cream celebration, Andy is again the recipient of magic power as he interprets what old John says: '’Cows in the sky?' I asked him. 'Is that what you said?' . . . He nodded. They were right, the words I'd heard. No one else ever understood anything he said ...”' (p. 20). Andy's ability to interpret both Onion John's words, actions, and emotions fuel this story's plot; the boy's many personality traits are often used to determine what to do in the subjective situations Onion John draws him into.

The story contains at least three plots. One involves Onion John and his interactions with Andy and his friends. The second includes Onion John, Andy, Andy's father, and his father's friends. The third 
revolves around Andy's relationship with his dad. So, first things first. Onion John is a mystical man who talks in indecipherable codes (for most people, that is), lives in an unconventional house, and has unorthodox ways of dealing with the problems in his world. Andy is charmed by him, and, because of his stable home life, is able to form opinions about the man with the care and concern of his parents.

When Onion John wants to try to break the drought by fasting, having a procession, carrying torches, singing, etc., Andy doesn't see what harm it could do to try: "It'll make him happy. And it can't do any harm. And what if it works? We'll be the first ones in Serenity who ever made it rain!” (p. 30). His dad is less sure that this spectacle will do no harm, but he respects Andy's right to learn for himself. When it pours three days later, Andy's dad is the first to congratulate the rain makers. However, when Onion John cooks up a Halloween plan to fumigate Andy's house of witches, dad draws a line in the sand: To be friends with Onion John either they have to regress to the fourteenth century ideas he has, or he has to be brought up to the $20^{\text {th }}$ century life they are living. Andy is not sure he wants to give up the rituals, secret codes, and excitement that Onion John brings, but he accepts the obvious choice. His dad puts flesh on the bones of the plan by suggesting that building Onion John a new, modern house would be a step in the right direction. Onion John is consulted, agrees, and sub-plot 2 is underway.

The Rotary Club and the members' wives are excellent examples of the formal perspective on leadership in action. They plan, schedule, assign, and act-all in an effort to construct Onion John's house on schedule. Andy helps in this effort, and from demolishing, to framing, to shingling and painting, he is there to interpret events for the rather confused Onion John. The stove and the bathtub cause Onion John to fret, and one of these modern devices later causes Andy's dad to do the same. When the house is finished, it is a marvel of modern construction. Andy helps Onion John prepare a speech to thank all those who helped. He steps out of the best-friend-of-OnionJohn spotlight, and he declares his father the best friend Onion John could have. But Andy himself takes the blame when Onion John burns down the new house, thinking that the new stove needed wood to fuel it. However, through conversations and musings, he comes to realize that the loss of the modern house is a good thing, for now Onion John can choose his own life for himself, even if that life includes ritualized gold-making and unorthodox goat-based remedies.

Likewise, Andy and his dad are learning something about shared decision making. Andy's dad sees the potential Andy has in science and math, and he dreams that Andy will become an astronaut. He even arranges a summer job for Andy at General Magneto, a local leader in technology. Rather than welcoming this opportunity, Andy realizes that it will take him away from his dad and their pleasant summers working together at the hardware store. He decides his only escape from a future that is being planned for him is to run away with Onion John. His parents get wind of the plan. Eventually, they reconcile in a way which values the worth of both parties' opinions. Andy's dad tells him his life is his to plan, and he leaves room for Andy to make his own decisions.

But Onion John already knew he was master of his own life, and he decides he will stick with the plan to run away. He feels that Andy has outgrown him, and he also wants to avoid having a new house built for him to replace the modern marvel that almost killed him. The town has learned a lesson about deciding someone else's future: Everyone agrees not to rebuild. Andy's dad has learned a lesson: Don't use others to make up for your own losses. And Andy learned a lesson: He can confidently make his own decisions, knowing his dad will support him because “the only [person he] ever come across, who's anything great, is [his dad]” (p. 241).

\section{Fifth place (2 of 2): Jacob Have I Loved by Katherine Paterson}

As good an example of the ambiguity perspective as The Slave Dancer, this tale falls to a lower place in the whole-book ranking because the main character is so consumed by jealousy she is almost crippled and because the book doesn't offer much help for her in the form of other leadership examples, because most of the characters we meet are as self-involved as she.

It doesn't take long to figure out what makes Louise Bradshaw, 13, tick. She's barely welcomed us to her world when she reveals that the very sound of her twin sister's voice makes her nauseated. Her 
animosity throughout the book seems to be fueled only by her own self-centered jealousy; the firstperson narrative form makes this negativism immediate and raw. Twin sister Caroline, her beauty and talent well-known, seems much better able to handle the comparisons that are inevitable in twinships.

For Louise is no slouch. She has talents which bode well for life on an island: a sense of humor, skill at poling a skiff and finding oysters, and a love for the water. She is unhealthily introspective, and she spends a lot of time figuring herself out. Unlike Billie Jo's (Out of the Dust), Louise's observations about life make her less believable, especially if extent of hardship in the two cases is compared. Louise and her sister live with both parents and a grandmother, and, though poor, they all work together to make a life on Rass Island in Chesapeake Bay.

Early on, Louise gets rid of her victim mentality long enough to set out on an adventure with her serious-minded friend Call. They stake out the house of a man who has just arrived on the island; Louise dreams that he may be a spy and that she will be hailed as a wartime hero. Using many admirable leadership skills-planning, adopting a code, and being observant-they come face-to-face with the mysterious man. He turns out to be a former island resident, and almost as mysterious as a spy: "If he was not a spy, if he was indeed Hiram Wallace, why had he come back after all these years ...?" (p. 83).

Louise catches crabs on the beach, and sells them to make money to help her family. She rationalizes keeping some of the money for herself, but makes a point to honor the conservative Christian values held by the islanders. She reminds the newcomer of the Biblical principles that guide the island, but realizes that her own life has its share of inconsistencies. She does reach out to another when she agrees to clean up the house of a neighbor, and she shows more love for cats than for her own sister. Her leadership-she quotes the commandments as her authority-spares the lives of many of the marauding felines. When Caroline comes up with an ingenious remedy to the cat problem, Louise's jealousy resurfaces.

Her heroic deeds continue. During a storm, she alerts Hiram and helps him get to safety in her own home. After the storm, she poles him to the wreckage of his house, imagining herself like "a wise [Egyptian] slave who can read and write and dare to advise their masters" (p. 129). She comforts Hiram as he realizes all is lost. Her chaotic feelings about him reveal an adolescent crush, one that causes her many ambivalent feelings as she and her family offer their home to him as a temporary refuge. She is miserable, and she lets those around her know it.

But the world keeps spinning, and time moves on. Through a chain of events involving Hiram and his past, a sum of money is entrusted to him. He credits Louise with giving him the idea, and announces that he is going to use the money to send Caroline to music school on the mainland. How does Louise interpret this good fortune?: "God had chosen to hate me" (p. 181).

With seemingly nothing left to lose in her miserable, overshadowed, self-dominated life, she negotiates a deal with her parents. She'll stay out of school so she can catch crabs with her father. She finds happiness in this teamwork, and she even manages to find humor in her grandmother's strange outbursts. But this doesn't last long. Her friend Call announces his marriage to Caroline, and Louise's jealousy flares again. Grandma hits her with a Bible when she quotes deprecating Scripture, and Louise is befuddled about how her own mother can abide this woman so calmly. Is there any hope that Louise will find balance in her life, or will she forever identify with the Biblical Esau, the outcast twin brother of Jacob, who was loved?

Balance comes in the form of schooling off the island, marriage, and a family. The final scene is of Nurse Louise, a new mother herself, nursing a weak newborn twin for a mother who was feeding the stronger sibling. She is a leader who has learned, finally, that those who give get more in return.

\section{Sixth place (1 of 2): The Trumpeter of Krakow by Eric P. Kelly}

As readers get further away from the top wholebook leadership ranking in the sample, even noble characters in the stories have a harder time measuring up to a Billie Jo or a Jessie Bollier, two well-rounded characters who perform their leadership tasks in believable ways. The trumpeter of Krakow, Pan Andrew, is a very noble man, as is his son, the future trumpeter. The fifteenth-century Polish patriot hides a national secret in his home, and he has sworn that he will deliver the object safely to the king. On the 
journey to do so, his son carries on the family tradition of doing good deeds. Josef, at 15, demonstrates many traits which serve him well in leadership roles: He observes, plans, thinks ahead, wonders, and, most of all, interprets situations. In addition, he is brave, intelligent, pious, and humble. These characteristics and actions help him foil a bandit, save a girl from a savage dog, and discover a place for him and his parents to stay in the beautiful city of Krakow. But life is about to take an unexpected turn, and the future of Poland seems to be falling into Josef's hands.

Literally into his hands. For his father, in addition to harboring a national treasure, also has a job to do in the city. He stands at each of the four sides of the tower of the Church of Our Lady Mary, and he plays the Heynal, a hymn to Mary "which every trumpeter in the church had in the past sworn to play each hour of the day and night- 'until death'” (p. 4). In the past, death had come to one trumpeter before he finished the song, and a new tradition of playing the song without the final notes began. It is this tune that Josef's father plays, and it is this broken tune that Josef wisely repairs to save the city.

He is a quick study and picks up the tune well. After a brief time of playing just one of the four Heynals with his father, his chance to go solo arrives. As the hourglass sands drop closer to the hourly duty, the same evil man who had threatened him and his family earlier in the tale shows up in the tower. He is after the hidden treasure, which Josef now learns is the Great Tarnov Crystal, and it is up to Josef alone to be sure that the traditions of the country-the Heynal and the crystal-are preserved. Can he do it? Fortunately, Josef had thought about just such a situation happening, and had arranged a code with Elzbietka, his friend. If he played the Heynal all the way through, she would know trouble was brewing. So he does. Elzbietka notices, alerts the authorities, and saves the day.

However, in an exciting twist, the author reveals that the crystal is not in his father's possession, but that it had fallen into the hands of the alchemist Kreutz; his selfish experiment to make gold from brass almost torches the entire city. He gives the crystal that he has hidden in his robes to Josef's father, and Kreutz declares madly that it is cursed. Realizing that the crystal must be delivered as quickly as possible, Josef, his father, Elzbietka, and the scholar-priest Jan Kanty set out with the alchemist to do so, thus fulfilling Josef's father's oath. The crystal's significance and history are made plain, and the king promises him a proper reward. All seems well. However, the alchemist, realizing the power of the stone, grabs it and throws it in the river, where it still rests: "There had been in its history too much of suffering and misfortune to make it a thing at all desirable to possess, in spite of the purity of its beauty” (p. 214). Josef's story, part of that suffering and misfortune, ends-happilywith his university education and his marriage to Elzbietka. He is a shining example of the positive characteristics of his people.

\section{Sixth place (2 of 2): M.C. Higgins, the Great by Virginia Hamilton}

In M.C., the reader meets the first and only black protagonist in the sample. Similar to his whole-book co-sixth-place finisher, M.C. takes family responsibility seriously, maybe too seriously. He and his family live in the shadow of an oily coal mine spoil heap that, M.C. believes, is going to dislodge and bury them. He is like a prophet, proclaiming doom and destruction to those who won't heed his words. His quest is to convince his dad to move, the outcome of which the reader doesn't learn until late in the tale.

Though his obsession makes him seem weak, 13year-old M.C. has many personality traits which equip him for his leadership roles. He is tall, intelligent, strong, imaginative, graceful, creative, has keen senses, and is in touch with people around him. He motivates a new friend to do an impossible thing, and he accepts the "witchy" six-fingered Killburn family. He, himself, is quasi-supernatural. M.C. has secret ways of doing things, and his visions and premonitions sometimes give him clues about the present. And why shouldn't he be all these things? He is "the Great" after all, and the 40-foot-pole in his yard that he sits atop seems a suitable throne for this God-pretender: "He fluffed the trees out there and smoothed out the sky. All was still and ordered, the way he like to pretend he arranged it every day” (p. 27).

He proves his greatness in a variety of ways. He loves his family, valuing the traditions and songs that have been passed down. He shows this love in at least three ways: First, "[m] ost of the time, the children were in M.C.'s care” (p. 72), because his father works, 
though sporadically. His mother's employment and M.C.'s hunting skill keep them from starving, and the pole he sits atop inspires them: "It had been M.C.'s fancy to make the children cherish the pole even more than they would have, by putting shiny wheels and hard-looking pedals on it” (p. 54). He resents his custodial role because he has responsibility but little power to make the decision to move, the one decision that would really benefit his family. Another way he cares for his family is by encouraging his mother: he recognizes that her singing talent may be their ticket out of the shadow of the slag heap, and he directs the recruiter to their home and orchestrates the audition. A third way he shows he cares for his family is his concern for his father and his drinking problem. M.C. is comfortable enough with his dad to negotiate about moving, but he also fears and misunderstands him. It takes his mom to sort out some of this relationship, and the information M.C. gains from her helps him cope.

But M.C. leads others too. He encourages a new friend to swim through a tunnel, taking her where she didn't even know she wanted to go: "They were in a world all their own, where she was older but he was the leader" (p. 157). He negotiates a good price for the supply of ice they need. Though he accepts the witchy Killburns and their six-fingered, ice-selling, snakecharming ways, he is wary of them. When he realizes that, despite their strange habits, their worldview makes sense, he accepts them.

His crowning achievement is the wall he builds at the end of the story. Accepting his mother's explanation for his father's unwillingness to move-the pole actually marks ancestral burial ground-M.C. begins building a wall. His father contributes the gravestones that he had tucked under the porch, and M.C., putting his own pride aside, accepts the building materials "to make the wall strong” (p. 277).

\section{Seventh place (1 of 2): Up a Road Slowly by Irene Hunt}

Julie lives in a house where something is "terribly wrong” (p. 2). Upset by news that she may be moving, she is sedated and sent off to live with her Aunt Cordelia. She describes herself in this first-person historical fiction account as overindulged. As she ages from 12 on, "self indulged" describes her best. To compound her troubles, her aunt is not only her no- nonsense guardian, she is also her emotionallydetached teacher. Uncle Haskell provides some comic relief in the plot, though his lying and thinly-disguised drinking hardly make him a good role model for this young person.

Her first act of leadership is to organize the ongoing shunning of a mentally-challenged schoolmate. Her next leadership role is to help her sister when her daughter, Julie's namesake, is born. Even this role is clouded by self-interest: She resents her brother-in-law's primary status in her sister's life. The pages in between these events have to do with her inner life and "manipula[tion] . . . in the world of adults” (p. 29). She's lonely, resentful, and dismissive of those who don't suit her purposes: "I had no interest in anyone's feelings save my own” (p. 37). Uncle Haskell does what he can to modify her character by talking to her and writing her pointed notes.

She does reach out to Aunt Cordelia, assisting in the kitchen, and she defends her aunt's strictness to a wealthy classmate. When her Father remarries, she is her one attendant. When it comes time for her to move back home, though, she negotiates to stay with Aunt Cordelia. She seems to be learning that marriage relationships do take priority, and her decision pleases all involved. In a rather Gothic twist, Julie helps tend to a woman who, out of her senses, wanders off and gets lost. She offers to help Brett, another classmate, with his schoolwork. Soon, he takes advantage of her intellect and, in another Gothic twist, of her infatuation with him. Uncle Haskell rescues her, and her integrity remains untarnished. With Aunt Cordelia's help, she recovers from her broken ego and heart, and finds room in her life for two new interests: Danny and writing. Contributing to her transformation, Uncle Haskell encourages her writing ability, (and dies soon after from a mysterious fall from the bridge), and little Julie "followed me around with a devotion I had never known before ...” (p. 147). The book ends with a characteristically narcissistic Julie glowing with pride at the applause rendered for her marvelous graduation speech.

\section{Seventh place (2 of 2): Missing May by Cynthia Rylant}

Once again, the Newbery award-winner is about an orphan. Summer tells the reader the story of her 
life with the aunt and uncle she has lived with for six of her twelve years. They are a loving couple who dote on Summer. Aunt May declares, "I always told [Uncle] $\mathrm{Ob}$ he was my moon and sun. And when you came to us, Summer, honey, you were my shining star” (p. 87). When May dies, this little universe spins out of kilter. Following his wife's advice to hold on to those you love (cf. Dicey), Ob decides that the way to restore balance is to contact May through a spirit interpreter, an idea planted in his head by Summer's friend Cletus. Summer is so afraid that Ob's grief is going to kill him, that she goes along with this plan "to mend his sorry broken heart" (p. 16).

Her care and concern for $\mathrm{Ob}$ are real and expressed often in word and deed. She cooks for him, encourages him to pursue his whirligig hobby, and tries to encourage him. Her own self worries are also real. She's not sure happiness is always around the corner, and she wishes that she were enough to make $\mathrm{Ob}$ want to go on. The formal systemized funeral parlor way of dealing with death has left her cold, and books and popular media offer no answers. She is on her own in helping $\mathrm{Ob}$.

Though she doubts that contacting May is possible, she sees it as her only hope: “. . . if it kept Ob grinning and chasing after some hope, I knew I'd have to be willing to follow him" (p. 54). Fortunately, some of her leadership burden has been shifted to Cletus, though she expresses doubts about the plan they have agreed to. After manipulating Cletus' parents so that Cletus can accompany them, they, "like three visitors heading for Oz," (p. 71), set out. Unfortunately, their savior, the Reverend Miriam Young of the Spiritualist Church, has died. They set out to return home; Summer is dejected, depressed, and worried, "praying for something to save $\mathrm{Ob}$ and me" (p. 76). That salvation comes in the form of a detour to the West Virginia state capitol, a place $\mathrm{Ob}$ revered. When Summer breaks down in grief as an owl, May's symbol, flies in front of her, Ob is able to comfort her, putting life back in her. The natural order is restored when $\mathrm{Ob}$ reclaims his parental duties and rediscovers the joy his whirligig hobby brought to him. In an authoritative, fatherly way, he states that the spirit messages' purpose is to console those who suffer. Summer's quest for Ob's healing seems to be over.

\section{Eighth place (1 of 1): A Gathering of Days: A New England Girl's Journal, 1830-32 by Joan Blos}

This first-person, historical fiction story begins with a letter from a great-grandmother to her namesake great-granddaughter, explaining that she, herself, penned the journal the year she turned 14. Similar to Out of the Dust, this story records details in the life of Catherine Hall, from daily events, to decision-making, to duties fulfilled. It is a tale of a life defined by goodness, guiding principles, and a girl's own discoveries about herself. Catherine is motherless (cf. Dicey, Billie Jo, and Julie), but loved by her father. She is virtuous and skillful, valuing good handwriting, selfdiscipline, and care for others. When confronted with a moral dilemma-helping a stranger who left her a note by giving him one of her mother's quilts-she agonizes over its many mysteries: Is the stranger a sinner or sinned against, slave or free, young or old? She feels sorrow for leaving her father and her best friend out of the discussion about what to do. She decides, after consulting with her friend Asa and weighing the principles involved in the matter, to leave a quilt in the woods for the stranger to warm himself. She confirms her decision in her mind by praying for the man on Christmas. Her phantom, as she calls him, is not through with her yet.

Life goes on. She's happy when spring comes, and she admires the schoolteacher for his stand on using classroom materials that advance moral development, though the materials are not approved by the school officials. She has a birthday and resents it when her father implies that her childhood has been taken from her because of her responsibilities (cf. Dicey). She wins a spelling bee, wisely uses their dwindling supply of food, mends, and does the family laundry. It appears that her adult-like duties may soon be over: Father has expressed interest in a new wife.

She is conflicted about this, "I will not call her mother” p. 75), and her emotions spill over when the missing quilt affair is revealed and her father's wife promises to help her make a new replacement one, the punishment decided on by the newlyweds. As the step-relationship grows, she begins to call her "Mammann"-a hybrid name which seems to fit the situation well. 
Crisis comes to Catherine when her friend Cassie dies. Guiding principles offered by others help her cope. She realizes that Cassie was dear to others too. Moving beyond self-pity helps restore order to her world of learning, farming, and news of unrest in the South. Aphorisms, Biblical sayings, and guiding principles are the wind in her sails as she moves on with life. When a letter arrives, written in the same handwriting as the message that began the quilt incident, Catherine learns that the man she helped is now free-and very grateful-in Canada.

Catherine discovers that life is full of opposing realities, and, as she prepares to leave home to care for her aunt's new baby, she leaves the reader with this characteristic dichotomy: “. . . [N]ever is a place so loved as when one has to leave it” (p. 142). Reminding the reader of the writer of the journal, the author ends the tale with a letter written, again, from the great-grandmother. It closes characteristically: "Life is like a pudding: it takes both the salt and the sugar to make a really good one” (p. 144).

\section{Ninth place (1 of 1): It's Like This, Cat by Emily Neville}

Meet Dave, a 14-year-old boy who decides to get a cat because his dad thinks a dog would be a good pet. Their bickering is a constant sub-plot in this book, though Dave does manage to overcome his adolescent rebellion long enough to convince his dad to help two of his friends. Neither of these humans, though, get as much page time as Cat, the pet who is loved because "[a]nything a cat does, he does only when he wants to” (p. 7) . He acquires the cat from Kate, a reclusive cat-lover who, later in the story, inherits her brother's fortune. Dave's dad helps her manage both the cats and the cash.

When Cat gets lost and Dave trespasses to find him, he meets Tom Ransom, a young man who is a suspected burglar. Because he is nicer than the superintendent of the New York apartment in which he lives, Dave hopes that Tom makes a big haul. There seems to be a guiding principle here, but moral doesn't describe it. Dave writes to him when he finds out he's in jail, and he and his family befriend and help Tom.

Dave's friend Nick is a little annoyed by Cat. He spoils a date he arranges for him, Dave, and two girls, though Dave's reluctance to interact with the opposite sex seems to be the real trouble here. Dave and Nick eventually come to blows, literally, and the friendship is put on hold.

Tom reappears, and, after meeting Dave's mom, he and his friend explore the sidewalks and subways of the city. He interprets Tom as "an island" (p. 46). His ex-friend Nick shows up and he and Dave start summer vacation together, a "dull routine" (p. 54). Then Tom reappears, with a girlfriend, and Dave and Hilda discuss what Tom should do with his life. Dave decides to enlist his dad's help, which he agrees to do. Dave takes the lead in suggesting employment, and his dad makes the contact. Tom gets the job.

One of Dave's biggest dilemmas is whether or not to have Cat neutered. He gets advice from others and decides that the surgery is in his wandering cat's best interest. Cat survives the surgery and Dave's worrying. Cat is the beneficiary of Dave's concern later when Dave braves traffic to rescue him.

Dave overcomes his girl-phobia and takes Mary, someone he met earlier, to see a play. The meeting wasn't prearranged, and Dave doubts that he has the skills needed to make the effort needed to pursue a relationship: "I sort of can't imagine calling up and saying, 'Oh, uh, Mary, this is Dave. You want to go to a movie or something, huh?'” (p. 78). So, he takes the lead by orchestrating another "chance" meeting, leaving the details to work themselves out. Mary lives a bohemian life, and Dave thinks about the differences between his family and her family. Dave gets annoyed with independent Mary; he wants to be in the lead, and she won't let him. When she turns to him for assistance, Dave recruits his dad and they help her.

Ben is the newest entry in Dave's cavalcade of friends. He attends school with him, and Dave introduces him to Tom and to New York's natural world. Tragedy strikes, however, when Cat pounces on the salamander that Ben captured. Dave and his dad agree to reduce bickering so Mom's asthma doesn't flare up; Dave gives Cat partial credit for bringing together some of the people in this tale.

\section{The Nature of Leadership}

The study focused on eight well-documented leadership perspectives, and, obviously, was crafted to affirm these perspectives given that the codes used to 


\section{It is instructive to note}

whether the dominant

perspectives (moral,

personality, ambiguity,

and subjective) are in-

dicative of a transforma-

tional or transactional

emphasis on leadership. gather data were constructed

from thirty-eight subcategories that describe the perspectives. And, indeed, every perspective was represented to one degree or another within the sample. It is instructive to note whether the dominant perspectives (moral, personality, ambiguity, and subjective) are indicative of a transformational or transactional emphasis on leadership. Burns (1978) makes the following distinctions between the two types: Transactional leaders engage in you-scratch-my-back, I'11-scratch-yours tactics to accomplish goals common to both parties. In transactional leadership, an exchange of goods is always made. These relationships can be short lived. In fact, Burns (1978) says that the relationship will last only as long as necessary; it is fluid and changeable. To use an analogy, transactional leaders are like merchants, exchanging, bartering, and trading to achieve goals.

Transformational leaders, on the other hand, are intellectuals who use criticism, imagination, and thought to affect ends beyond present means. Transformational leadership links people together by inspiring engagement with one another so that a common purpose is achieved; trust, vision, and empowerment mark transformational leadership (Burns, 1978; Carlson, 1996). Transformational leaders are like gardeners, tending to the needs and growth of others. This study favors transformational leadership, because most of the four top-ranked perspectives favor a transformational approach: Moral and subjective are part of a transformational emphasis, personality is either, depending on the leader's qualities, while the ambiguity perspective is the only leading perspective clearly not within the transformational emphasis.

\section{The Value of Adolescent Literature in the Formation of Leadership Characteristics}

Adolescents want to make sense of the world, of good and bad, of work, even of death; these are the themes of literature, especially literature that has withstood the test of time (Probst, 1984). Kinman and Henderson (1985, p. 887) highlight the importance of realistic fiction:

Adolescents are confused over what they will become, as well as who they are, and they role play attitudes and behaviors. Literature then must deal with characters assuming adult behaviors and searching for adult identity. The books' characters and situations must have an element of reality: Readers can then accept that the character's experiences are similar to their own.

Because adolescent readers live in the present moment, the books that appeal to them probably will be "grounded in the realities of their own lives" (Hamilton, 2002, p. 61). The study I conducted was crafted to analyze these books in light of Probst's, Kinman and Henderson's and Hamilton's parameters. Newberys have withstood the test of time and the sample correlates to the lives (as measured by characters' ages and realistic story lines) adolescents live. "It is true now, as it was true when John Newbery published children's books, that what is published for children reflects the contemporary society's opinions of what children should read ..." (Sutherland, 1997).

The content analysis and summaries presented here are intended to give readers another tool to use as they choose books that will help grow adolescent readers and leaders. This study should serve as a valuable tool for those who wish to harness the implicit themes in stories to help develop leaders who are aware of the transactive and transformative powers of leadership. It affirms Burns' conclusions, which are based on theories of need hierarchy, moral development, and personal growth: "If the origin of the leader's value system lies in childhood conscience, adolescence and adulthood bring new overtures and new closures as norms are interpreted and applied in ever-widening, ever more differentiated social collectives (1978, p. 73). Adolescent experiences with literature could very well be a "new overture" in the development of leadership attributes and characteristics. Fiedler (1971) and Burns (1978) say that adolescent leadership is spontaneous and not influenced by overt attempts to develop it; therefore, implicit messages may be a powerful influence. This study helps one begin to understand adolescent leadership in this way (using dominant sub-categories as the sources for the descriptors): The adolescent leader is 
Table 2: Whole-book Ranking in Five categories

\begin{tabular}{|c|c|c|c|c|c|c|c|}
\hline & $\begin{array}{l}\text { 1. Strong } \\
\text { Leadership } \\
\text { Perspective }\end{array}$ & $\begin{array}{c}2 . \\
\text { Believable } \\
\text { Tasks }\end{array}$ & $\begin{array}{c}3 . \\
\text { Balanced } \\
\text { Protagonist }\end{array}$ & $\begin{array}{c}4 . \\
\text { Engaging } \\
\text { Story }\end{array}$ & $\begin{array}{c}5 . \\
\text { Other } \\
\text { Leaders }\end{array}$ & Total & $\begin{array}{c}\text { Whole- } \\
\text { book } \\
\text { Rank }\end{array}$ \\
\hline Trumpeter of Krakow & 4 & 3 & 2 & 3 & 2 & 14 & $6^{\text {th }}$ \\
\hline Young Fu of the Upper Yangtze & 4 & 5 & 4 & 3 & 3 & 19 & $4^{\text {th }}$ \\
\hline Johnny Tremain & 5 & 5 & 4 & 3 & 5 & 22 & $2^{\text {nd }}$ \\
\hline Onion John & 3 & 3 & 3 & 2 & 5 & 16 & $5^{\text {th }}$ \\
\hline It's Like This, Cat & 1 & 1 & 2 & 1 & 2 & 7 & $9^{\text {th }}$ \\
\hline Up a Road Slowly & 1 & 2 & 3 & 2 & 2 & 10 & $7^{\text {th }}$ \\
\hline The Slave Dancer & 5 & 4 & 5 & 5 & 4 & 23 & $1^{\text {st }}$ \\
\hline M.C. Higgins, the Great & 5 & 3 & 2 & 2 & 2 & 14 & $6^{\text {th }}$ \\
\hline A Gathering of Days & 1 & 2 & 3 & 1 & 2 & 9 & $8^{\text {th }}$ \\
\hline Jacob Have I Loved & 5 & 4 & 2 & 3 & 2 & 16 & $5^{\text {th }}$ \\
\hline Dicey's Song & 5 & 5 & 4 & 4 & 5 & 23 & $1^{\text {st }}$ \\
\hline Missing May & 1 & 1 & 4 & 2 & 2 & 10 & $7^{\text {th }}$ \\
\hline The Midwife's Apprentice & 5 & 4 & 4 & 3 & 3 & 19 & $4^{\text {th }}$ \\
\hline Out of the Dust & 5 & 4 & 5 & 5 & 2 & 21 & $3^{\text {rd }}$ \\
\hline A Year Down Yonder & 2 & 4 & 5 & 3 & 5 & 19 & $4^{\text {th }}$ \\
\hline A Single Shard & 5 & 4 & 4 & 5 & 5 & 23 & $1^{\text {st }}$ \\
\hline Crispin: Cross of Lead & 5 & 4 & 4 & 4 & 4 & 21 & $3^{\text {rd }}$ \\
\hline
\end{tabular}

emotionally connected to others (1.3) as s/he willingly shares responsibility (3.3) in a selfless way (7.3), as s/ he discovers solutions (5.1) to confusing leadership situations (6.2), and as s/he feels both interested (5.1) and uncertain (6.1) about the leadership situation.

If educators are to transform culture, they must critically examine the implicit and explicit curricula and materials that inhabit the classroom. This study will enable decision-makers to understand what kinds of adolescent leaders are hiding in exemplary literature and to use this understanding to transform culture.

Carol Jasperse Lautenbach teaches English Language Arts at Lee Middle School in Wyoming, Michigan and Secondary Content Area Literacy at Calvin College, Grand Rapids, Michigan. She earned her doctorate in Educational Leadership from Western Michigan University, Kalamazoo, Michigan.

\section{Works Cited}

Avi. Crispin, the Cross of Lead. New York: Hyperion, 2002. Blos, J. A Gathering of Days. New York: Aladdin, 1979. Bush, T. Theories of Educational Management. London: Paul Chapman, 1995.

Carlson, Robert. Reframing and Reform. White Plains, NY: Longman, 1996.

Cushman, Karen. The Midwife's Apprentice. New York: HarperCollins, 1995.
DuPree, Max. Leadership is an Art. Englewood Cliffs, NJ: Media Books, 1990.

Fiedler, Fred. A Theory of Leadership Effectiveness. New York: McGraw Hill, 1967.

Forbes, Esther. Johnny Tremain. New York: Bantam Doubleday Dell, 1943.

Fox, Paula. The Slave Dancer. New York: Bantam Doubleday Dell, 1973.

Friedman, Audrey, \& Cataldo, Christina. "Characters at Crossroads: Reflective Decision Makers in Contemporary Newbery books." The Reading Teacher, 56.2 (2002): 102-112.

Gardner, Howard. Leading Minds: An Anatomy of Leadership. New York: Basic Books, 1995.

Greenleaf, Robert. Servant. Peterborough, NH: Windy Row Press, 1980.

Hamilton, Gregory. "Mapping a History of Adolescence and Literature for Adolescents." The ALAN Review, 29.2 (2002): 57-62.

Hamilton, Virginia. M.C. Higgins, the Great. New York: Aladdin, 1974.

Hanna, Geneva. "Promoting Adolescent Growth Through Reading." In Thomison, Dennis (Ed.), Readings about Adolescent Literature. Metuchen, NJ: Scarecrow, 1964.

Hayden, Gretchen. A Descriptive Study of the Treatment of Personal Development in Selected Children's Fiction Books Awarded the Newbery Medal. Doctoral dissertation, Wayne State University, 1969.

Hesse, Karen. Out of the Dust. New York: Scholastic, 1997. House, Robert. "A 1976 theory of charismatic leadership." In J. Hunt \& L. Larson (eds.), Leadership: The cutting edge (pp. 189-207). Carbondale, IL: Southern Illinois University Press, 1977. 
Hunt, Irene. Up a Road Slowly. New York: Berkley Jam, 1966.

Kelly, Eric. The Trumpeter of Krakow. New York: Aladdin, 1928.

Kinman, Judith, \& Henderson, Darwin. "An Analysis of Sexism in Newbery Medal Award Books from 1977 to 1984." Reading teacher, 38.9 (1985): 885-889.

Krumgold, Joseph. Onion John. New York: HarperCollins, 1959. Lewis, Elizabeth. Young Fu of the Upper Yangtze. New York: Holt, Rinehart and Winston, 1932.

Moshman, David. Adolescent Psychological Development: Rationality, Morality, and Identity. Mahwah, NJ: Lawrence Erlbaum Associates, Inc., 1999.

Neville, Emily. It's Like This, Cat. New York: HarperCollins, 1963. Northouse, Peter. Leadership Theory and Practice. Thousand Oaks, CA: Sage, 1997.

Park, Linda Sue. A Single Shard. New York: Dell, 2001.

Paterson, Katherine. Jacob Have I Loved. New York: HarperCollins, 1980.
Peck, Richard. A Year Down Yonder. New York: Penguin, 2000. Pfeffer, Jeffrey. Managing with Power: Politics and Influence in Organizations. Boston: Harvard University Press, 1992.

Probst, Robert. Adolescent Literature: Response and Analysis. Columbus, OH: Charles E. Merrill Publishing Company, 1984.

Rylant, Cynthia. Missing May. New York: Bantam Doubleday Dell, 1992.

Sergiovanni, Thomas, \& Starratt, Robert. Supervision: A Redefinition. Boston: McGraw Hill, 1998.

Starratt, Robert. The Drama of Leadership. London: The Falmer Press, 1993.

Sutherland, Zena. "The Newbery at 75: Changing with the Times." American Libraries, 28.3 (1997): 34-36.

Voigt, Cynthia. Dicey's Song. New York: Simon \& Schuster, 1982.

Yukl, Gary. Leadership in Organizations (4th ed.). Upper Saddle River, NJ: Prentice Hall, 1998. 